\title{
Multinational Military Operations at Sea
}

\section{Anna Petrig*}

\begin{abstract}
Multinational military operations have extended to the sea. These operations mirror the changing maritime security landscape wherein transnational crime has become one of the most prominent security threats. With this, the traditional war-related role of navies has slowly but steadily been supplanted by a new function: policing the sea. This new role is more often than not carried out by navies working together, either as naval coalitions or as highly integrated naval forces of regional organizations. This Chapter describes the 'legal pluriverse' in which such multinational military operations at sea take place. It first asserts that such operations are not 'warfare lite', but rather determined by peace time law. It then proceeds to take stock of the rules authorizing multinational forces and contributing states to enforce the law at sea. In a last step, the legal bases imposing strictures on the exercise of these enforcement powers are carved out. The Chapter concludes that the legal framework governing enforcement jurisdiction at sea is arguably the epitome of a 'legal pluriverse', yet the powers are more clearly defined than the strictures attaching to their exercise.
\end{abstract}

Keywords: military operation, law enforcement, policing, multinational, NATO, sea, maritime, UNCLOS, Security Council, law of the sea

\section{Introduction}

Multinational military operations have extended to the sea. With the deployment of three multinational forces to counter piracy off the coast of Somalia a decade ago, the first truly internationalized law enforcement operation at sea went into effect. At the time of writing, EUled naval forces, with the support of NATO forces, are working towards the suppression of migrant smuggling and human trafficking in the Mediterranean and enforcing the arms embargo imposed by the Security Council on Libya. These operations mirror the changing security landscape, one in which criminal activity by non-state actors is steadily becoming a main security threat. This altered landscape has led to a new role for navies where they are increasingly engaged in policing the sea - that is, missions 'other than war'. This Chapter

* Anna Petrig is Professor of International Law and Public Law at the University of Basel in Switzerland. She would like to thank Maria Orchard, J.D./LL.M., for her instrumental research assistance and discussions on the topic. The usual disclaimers apply. 
describes the 'legal pluriverse' in which such multinational law enforcement operations at sea take place and proceeds in three steps. First, the legal paradigm governing these operations is identified, which is clearly peacetime law rather than the law of armed conflicts at sea (Part I). Second, the Chapter takes stock of the rules authorizing multinational forces and/or contributing states to enforce the law at sea (Part II). In a last step, the legal bases imposing strictures on the exercise of these enforcement powers are carved out (Part III).

\section{Changing Security Landscape, Changing Role for (Multinational) Naval Forces}

It has been suggested, and will be explained in further detail now, that the security landscape has changed considerably since the turn of the millennium - and this holds true in the maritime setting as well (2.1). With classic interstate conflicts at sea fading from the spotlight and the suppression of transnational crime coming to the fore, the traditional war-related role of navies has slowly but steadily been supplanted by a new function: policing the sea. This new role is more often than not carried out by navies working together, either as naval coalitions or as highly integrated naval forces of regional organizations (2.2).

\subsection{Maritime threats emanating from non-state actors}

Before the end of the Cold War, the main scenario envisaged by maritime strategists was an interstate conflict at sea. In today's globalized world, by contrast, the maritime security challenges are considerably more diverse. In particular, illegal acts committed by non-state actors at sea have entered the limelight. ${ }^{1}$ The concept of 'maritime security' began to emerge following a spate of terrorist attacks against vessels occurring in the wake of $9 / 11,{ }^{2}$ and the rise of Somali-based piracy after 2006 ultimately brought it to the forefront. ${ }^{3}$ In its 2008 Report on Oceans and the Law of the Sea, the Secretary General identified seven specific threats to maritime security, which are: piracy and armed robbery; terrorist acts involving shipping, offshore installations and other maritime interests; illicit trafficking in arms and weapons of mass destruction; illicit trafficking in narcotic drugs and psychotropic substances; smuggling and trafficking of persons by sea; illegal, unreported, and unregulated fishing; and intentional and unlawful damage to the marine environment. ${ }^{4}$

Most of these criminal phenomena occur in regional settings, yet their effects may go well beyond the locus delicti and affect distant societies. Somali pirates, for example, (initially) operated within very limited geographical parameters, but the attacks affected a critical sea lane, and piracy - perceived as a threat 'to international navigation and the safety of commercial

\footnotetext{
${ }^{1}$ NATO Parliamentary Assembly, 'Maritime Security, NATO and EU Roles and Co-ordination' (Committee Report, 207 CDS 10Ebis, 19 November 2010) paras 6, 8, 15. $<$ www.ft.dk/samling/20101/almdel/npa/bilag/5/925749.pdf> accessed 15 January 2018.

2 On these and other terrorist attacks against ships, see Geoffrey Till, Seapower: A Guide for the TwentyFirst Century (3rd edn, Routledge 2013) 292-93.

${ }^{3}$ Christian Bueger, 'What is maritime security?' [2015] 53 Marine Policy 159, 159.

${ }^{4}$ UNGA, 'Oceans and the law of the sea: Report of the Secretary-General' (10 March 2008) UN Doc A/63/63, paras 54-113.
} 
maritime routes, and to other vulnerable ships' - even prompted action by the Security Council. ${ }^{5}$ The other security threats addressed in the Secretary General's Report also illustrate what is referred to as globalization of security, meaning that states engage in constabulary action in distant theatres in order to defend their own security - especially in situations where the coastal or flag state is unwilling and/or unable to enforce the law itself. ${ }^{6}$ Hence, the 'home game' of security, i.e. law enforcement by a state in its own waters or against its own vessels, was expanded to an 'away game'7 that aims at securing access to the sea, one of the global commons $^{8}$ and protecting the maritime transportation systems as a whole rather than solely their own merchant fleet. ${ }^{9}$

\section{2 (Cooperating) navies as main actors in the 'away game'}

As a general rule, only navies have the operational capacity to engage in the 'away game' and to sustain law enforcement operations at sea in distant theatres over longer periods of time. This is due to the simple fact that civilian agencies - in many states, the coast guard - rarely possess ocean-going vessels. ${ }^{10}$ This, taken together with the changing security landscape at sea, means that navies today are increasingly involved in missions 'other than war', which differ from traditional military tasks (i.e. conduct of hostilities) and pertain to the criminal rather than the military domain. In short, navies are conducting policing functions (i.e. law enforcement), ${ }^{11}$ and for some navies, constabulary operations are even their principal employment. ${ }^{12}$

Depending on the division of tasks between civilian and military agencies under domestic law, navies traditionally fulfil certain constabulary tasks, such as the enforcement of customs, immigration and fisheries law. ${ }^{13}$ These 'home game' enforcement activities are generally carried out in waters under the sovereignty of the enforcing state or against ships flying its flag - and by that state alone. ${ }^{14}$ Maritime law enforcement operations discussed here differ in at least two

${ }^{5}$ UNSC Res 1846 (2 December 2008) UN Doc S/RES/1846, preambular para 2.

${ }^{6}$ NATO Parliamentary Assembly (n 1) para 18.

7 Till (n 2) 283.

8 Jo G Gade and Paal Sigurd Hilde, 'NATO and the Maritime Domain' in Jo Inge Bekkevold and Geoffrey Till (eds), International Order at Sea (Palgrave MacMillan 2016) 120.

9 Ivan T Luke, 'Naval Operations in Peacetime: Not Just "Warfare Lite"' [2013] 66 Naval War College Review 11, 13.

${ }^{10}$ See in more details Part II/B.

${ }^{11}$ Matteo Tondini, 'The use of force in the course of maritime law enforcement operations' [2017] 4 Journal on the Use of Force and International Law 253, 253 and 256-57; Luke (n 9) 12; James Kraska and Raul Pedrozo, International Maritime Security Law (Martinus Nijhoff 2013) 49.

12 Steven Haines, 'War at sea: Nineteenth-century laws for twenty-first century wars?' [2016] 98 International Review of the Red Cross 419, 424.

${ }^{13} \mathrm{Eg}$ the Canadian Royal Navy: See Ben Lombardi, 'The Future Maritime Operating Environment and the Role of Naval Power' (Defence Research and Development Canada, DRDC-RDDC-2016-R085, May 2016) S. 69 <http://cradpdf.drdc-rddc.gc.ca/PDFS/unc229/p803867_A1b.pdf> accessed 1 March 2018.

14 Cooperation between neighbouring states is not unusual (see eg Integrated Cross-border Law Enforcement Operations Act (Statutes of Canada 2012, chap. 19, sec. 368)); yet this is not truly internationalized law enforcement as contemplated here. 
respects. First, they take place in international waters (and, at times, even in the internal and territorial waters of third states as evidenced by the Somali counter-piracy operations) or against foreign-flagged vessels. Second, they are carried out collectively with other states and/or regional organizations in varying degrees of concertation and cooperation, as generally no single state has the resources necessary to counter contemporary maritime security threats. ${ }^{15}$

Such cooperation is encouraged by treaties aimed at suppressing transnational crime and by the law of the sea, which is said to have shifted from a paradigm of separation (preventing naval warfare by keeping maritime powers apart) to one of cooperation (bringing navies together to pursue matters of common interest). ${ }^{16}$ Yet, cooperation duties are either qualified ${ }^{17}$ or nonmandatory from the outset. ${ }^{18}$ What is more, mounting a multinational operation - the most farreaching form of cooperation, defined as 'military actions conducted by forces of two or more nations, usually undertaken within the structure of a coalition or alliance'19 - is determined by the political climate rather than cooperation duties under international law. In the past decade, such political will has been garnered on more than one occasion at the level of both the European Union (EU) and the North Atlantic Treaty Organization (NATO).

Counter-piracy operations off the coast of Somalia are the flagship in terms of cooperation between naval forces. No less than three multinational missions contributed to the counterpiracy efforts: the Combined Maritime Forces, a United States-led international naval coalition contributing with Coalition Task Forces 150 and 151 respectively; NATO's deployment of three consecutive operations - Operation Allied Provider, Operation Allied Protector and Operation Ocean Shield - between 2008 and 2016; and (the first ever) EU-led naval forces EUNAVFOR engaging in Operation Atalanta since 2008. Thereby, the Shared Awareness and Deconfliction (SHADE) initiative contributed to 'de-confliction', i.e. to the avoidance of redundant or conflicting activities of the (unprecedented) number of states and coalitions enforcing the law in one theatre. ${ }^{20}$

15 NATO (n 1) para 18; Bueger (n 3) 163.

${ }^{16}$ James Kraska, 'Grasping "The Influence of Law on Sea Power"' [2009] 62 Naval War College Review 113, 113.

${ }^{17}$ Eg Art 100 United Nations Convention on the Law of the Sea (adopted 10 December 1982, entered into force 16 November 1994) 1833 UNTS 3 (hereafter UNCLOS) ('to the fullest extent possible'); Art 7 Protocol against the Smuggling of Migrants by Land, Sea and Air, supplementing the United Nations Convention against Transnational Organized Crime (adopted 15 November 2000, entered into force 28 January 2004) 2241 UNTS 480 (hereafter Protocol on Migrant Smuggling) ('to the fullest extent possible').

${ }^{18}$ Eg Art 27 United Nations Convention against Transnational Organized Crime (adopted 15 November 2000, entered into force 29 September 2003) 2225 UNTS 209 ('shall consider entering into (...) agreements or arrangements on direct cooperation between their law enforcement agencies' (emphasis added); UNODC, 'International Framework for Action - To Implement the Smuggling of Migrants Protocol' (2012) 110-11 <www.unodc.org/documents/human-trafficking/MigrantSmuggling/Framework_for_Action_Smuggling_of_Migrants.pdf> accessed 15 January 2018.

19 US Department of Defense, 'DOD Dictionary of Military and Associated Terms' (August 2017) 159 $<$ http://www.jcs.mil/Portals/36/Documents/Doctrine/pubs/dictionary.pdf> accessed 7 March 2018.

20 UNSC, 'Report of the Secretary-General on the situation with respect to piracy and armed robbery at sea off the coast of Somalia' (12 October 2017) UN Doc S/2017/859, paras 4-5, 37-40; UNSC Res 2383 
Counter-terrorism operations are another field of activity of the Combined Maritime Forces (notably Coalition Task Force 152) ${ }^{21}$ and NATO's Operation Active Endeavour, which evolved out of NATO's response to the 9/11 terrorist attacks and ended in 2016. During the operation's lifetime, NATO forces patrolled the Mediterranean in order to deter and disrupt terrorist activity and hailed more than 128,000 merchant vessels and boarded a total of 172 suspected ships. ${ }^{22}$ The newly launched Operation Sea Guardian also features a counter-terrorism component. ${ }^{23}$

At the time of writing, EUNAVFOR's Operation Sophia is contributing to the disruption of the business model of migrant smuggling and human trafficking networks in the Southern Central Mediterranean and to the enforcement the arms embargo imposed by the Security Council on Libya. ${ }^{24}$ In fulfilling this mandate, it receives support from NATO's Operation Sea Guardian. ${ }^{25}$ As regards the enforcement of the arms embargo on Libya specifically, NATO deployed Operation Unified Power in 2001, during the course of which a total of 3,100 vessels were hailed, around 300 boarded and 11 denied transit to or from Libya. ${ }^{26}$ This is just one of many examples where NATO took an active part in embargo enforcement. ${ }^{27}$

This new operational reality has found its way into strategic-doctrinal documents, namely NATO's Alliance Maritime Strategy of $2011^{28}$ and the EU Maritime Security Strategy of 2014. ${ }^{29}$ These documents evidence how the maritime dimension of security has risen in rank on their

(7 November 2017) UN Doc S/RES/2383, preambular para 13; Robin Geiss and Anna Petrig, Piracy and Armed Robbery at Sea: The Legal Framework for Counter-Piracy Operations in Somalia and the Gulf of Aden (Oxford University Press 2011).

${ }^{21}$ Combined Maritime Force, 'CTF 150: Maritime Security' <https://combinedmaritimeforces.com/ctf-150maritime-security/> accessed 15 January 2018.

22 NATO, 'Operation Active Endeavour' (last updated 27 October 2016) $<$ www.nato.int/cps/en/natohq/topics_7932.htm> accessed 15 January 2018. Kraska and Pedrozo (n 11) 54.

23 NATO, 'Operation Sea Guardian' (last updated 27 October 2016) $<$ www.nato.int/cps/en/natohq/topics_136233.htm> accessed 15 January 2018.

${ }^{24}$ Council Decision (CFSP) 2015/778 of 18 May 2015 on a European Union military operation in the Southern Central Mediterranean (EUNAVFOR MED) [2015] OJ L122/31, Art 1.

${ }^{25}$ NATO, 'Progress report on the implementation of the common set of proposals endorsed by NATO and EU Councils on 6 December 2016' (NATO, 14 June 2017) 3 $<$ www.nato.int/nato_static_fl2014/assets/pdf/pdf_2017_06/20170619_170614-Joint-progress-report-EUNATO-EN.pdf> accessed 15 January 2018; NATO, 'NĀTO and EU discuss future cooperation at sea' (30 June 2017) <www.nato.int/cps/en/natohq/news_145749.htm> accessed 15 January 2018.

26 NATO, 'Operation UNIFIED PROTECTOR Final Mission Stats' (2 November 2011) $<$ www.nato.int/nato_static_fl2014/assets/pdf/pdf_2011_11/20111108_111107factsheet_up_factsfigures_en.pdf> accessed 15 January 2018.

${ }^{27}$ For further examples, see Martin D Fink, 'Maritime Embargo Operations: Naval Implementation of UN Sanctions at Sea under Articles 41 and 42 of the UN Charter' [2013] 60 Netherlands International Law Review 73.

28 NATO, 'Alliance Maritime Strategy' (last updated 17 June 2011) <www.nato.int/cps/ua/natohq/official_texts_75615.htm> accessed 15 January 2018; Gade and Hilde (n 8) 123.

${ }^{29}$ Council Strategy (11205/14) of 24 June 2014 on European Union Maritime Security [2014]. 
respective security agendas ${ }^{30}$ and acknowledge the policing function navies have increasingly assumed in the past decade. ${ }^{31}$ What is more, they may promote the deployment of additional multinational law enforcement operations in the future. This warrants further emphasis in Part 3 that these operations are governed by peacetime law.

\section{Multinational Law Enforcement at Sea: Governed by Peacetime Law}

If the navies are policing the sea, their operations are governed by a law enforcement paradigm, i.e. peacetime law. Doubts in that respect - and the idea that the law governing armed conflicts at sea could apply instead - may arise for a number of reasons, which are described in the following: because the measures taken by the enforcers feature an (only apparent!) similarity with the exercise of belligerent rights (3.1); because military rather than civilian assets are deployed (3.2); because enforcement measures may take place in contexts where an armed conflict is ongoing (3.3); and ultimately because of the use of the term 'Maritime Security Operation', obscuring the nature of the operations subsumed under this operational rather than legal term (3.4).

\subsection{No exercise of belligerent rights}

For an 'untrained eye' it may be difficult to determine from the outside whether a specific measure is authorized and confined by the law of naval warfare (hence, amounts to an exercise of belligerent rights) or by peacetime law, notably the law of the sea and further sources laid out in detail below (hence, amounts to a law enforcement measure). Not only are the measures similarly named, but in some cases may not be operationally distinguishable from each other, i.e. the practical actions looks alike under both regimes. ${ }^{32}$ For example, under both legal regimes (wartime and peacetime law) ships may be stopped, boarded and searched, and cargo seized. ${ }^{33}$

From a legal point of view, however, it is of utmost importance to ascertain under which legal regime a specific measure is taken since the conditions for their authorization (e.g. against which ships they may be taken), the limitations to observe (e.g. in terms of use of force), and the legal consequences are regulated very differently under the law of naval warfare as compared to peacetime law. As long as multinational operations are deployed to suppress criminal acts at

${ }^{30}$ Christian Bueger and Timothy Edmunds, 'Beyond seablindness: A new agenda for maritime security studies' [2017] 93 International Affairs 1293, 1294 and 1297-98.

${ }^{31}$ Gade and Hilde (n 8) 123, note that AMS 'places near exclusive emphasis on non-traditional security challenges' and '[m]ore traditional security challenges of the type NATO faced during the Cold War are not mentioned'.

32 Rob McLaughlin, 'Authorizations for Maritime Law Enforcement Operations' [2016] 98 International Review of the Red Cross 465, 490, states that 'to the untrained eye [maritime law enforcement powers] can represent a rough facsimile of many aspects of the law of naval warfare'; Wolff Heintschel von Heinegg and Martin D Fink, 'Maritime Interception/Interdiction Operations' in Terry D Gill and Dieter Fleck (eds), The Handbook of International Law of Military Operations (2nd edn, OUP 2015) 423.

${ }^{33}$ See Efthymios Papastavridis, The Interception of Vessels on the High Seas: Contemporary Challenges to the Legal Order of the Oceans (Hart Publishing 2013) Chapter 3, describing 'The Right of Visit on the High Seas in Wartime' in a first step, to then turn to 'The Right of Visit on the High Seas in Peacetime'. 
sea - most of which amount to offences defined under international law ${ }^{34}$ - they are governed by the law enforcement paradigm. ${ }^{35}$

\subsection{Law of the sea foresees the use of warships}

This finding is not altered by the fact that military personnel and warships are deployed to suppress criminal acts at sea. Rather, the law of the sea itself provides for the use of warships next to other ships on government service, such as police and patrol boats - for law enforcement operations at sea. ${ }^{36}$ In the Articles Concerning the Law of the Sea of 1956, which has had a profound impact on major law of the sea codifications, the International Law Commission even suggested to exclusively authorize warships when policing the sea because 'the use of other government ships does not provide for the same safeguards against abuse' or, put differently, for reasons of legal certainty. ${ }^{37}$ The drafters of the 1958 Convention on the High Seas and of UNCLOS did not retain this limitation. Hence, both warships and other ships under government service can be employed for law enforcement operations at sea.

The choice between military and civilian assets namely hinges on the division of tasks between military (naval forces) and civilian agencies (e.g. coast guards or border patrols) under domestic law. The extent to which states are willing to rely on their navies for enforcement purposes varies. ${ }^{38}$ Moreover, for law enforcement operations abroad specifically, the choice between military and civilian actors is influenced by operational considerations: only vessels of a considerable size and with specific equipment, i.e. traditional warships such as frigates and destroyers, ${ }^{39}$ have the capacity to remain in maritime areas far from the coast for longer periods of time and in adverse conditions. The fact that Japan's Coast Guard is one of a handful possessing ocean-going vessels ${ }^{40}$ explains why military (navies) rather than civil forces are the

${ }^{34}$ Acts suppressed in the course of counter-piracy operations may, inter alia, fulfil Art 101 UNCLOS (n 17); Art 3 Convention for the Suppression of Unlawful Acts Against the Safety of Maritime Navigation (adopted 10 March 1988, entered into force 1 March 1992) 1678 UNTS 221 (hereafter SUA Convention) or Art 1 International Convention against the Taking of Hostages (adopted 17 November 1979, entered into force 3 June 1983) 1316 UNTS 205 (hereafter Hostage Convention). Acts suppressed in the course of operations to counter illegal migration in the Mediterranean may, inter alia, fulfil the offenses defined in Art 3 juncto Art 6 Protocol on Migrant Smuggling (n 17), or Art 3 juncto Art 5 Protocol to Prevent, Suppress and Punish Trafficking in Persons, Especially Women and Children, supplementing the United Nations Convention against Transnational Organized Crime (adopted 15 November 2000, entered into force 25 December 2003) 2237 UNTS 319 (hereafter Protocol on Human Trafficking)

${ }^{35}$ Heintschel von Heinegg and Fink (n 32) 423; McLaughlin (n 32) 490.

${ }^{36}$ See, eg, UNCLOS (n 17) arts 107, 110(1) and (2), 224.

37 ILC, 'Articles concerning the Law of the Sea with commentaries' in 'Report of the International Law Commission covering the work of its eighth session' (23 April-4 July 1956) UN Doc A/3159, Art 45; see also 280 (comment on Article 33 - Immunity of government ships) and 283 (comment on Art 45).

38 Till (n 2) 316.

${ }^{39}$ A ship qualifies as a warship irrespective of its size and construction for so long as it fulfils the definitional criteria of a warship laid down in Art 29 UNCLOS (n 17): Wolff Heintschel von Heinegg, 'Warships' (Max Planck Encyclopedia of Public International Law October 2015) para 7 <http://opil.ouplaw.com/view/10.1093/law:epil/9780199231690/law-9780199231690-e443> accessed 7 March 2018.

40 Till (n 2) 295. 
key actors in multinational law enforcement operations. ${ }^{41}$ Yet, this does not alter the law enforcement character of the respective operations - as aptly stated in a NATO committee report: 'warships engaged in counter-piracy operations are treated as police or law enforcement forces'. ${ }^{42}$

\subsection{Law enforcement in situations of ongoing armed conflict}

It is not unusual for multinational operations mandated with countering criminal activity to be deployed to regions where armed conflicts are ongoing. Not least because the Security Council authorizes enforcement measures specifically in situations where, due to an armed conflict, no effective government exists which is able to effectively enforce the law in its internal waters and territorial sea (failed/failing state situation). Furthermore, the Security Council regularly issues authorizations in the field of embargo enforcement. Such embargos are likely to be imposed upon a state involved in an armed conflict in order to interrupt arms flows and/or to cut revenues from oil, charcoal, or other resources. ${ }^{43}$

In some (but not all) of these resolutions, the Security Council stated that the exercise of the authorized measures must be in compliance with 'international humanitarian law and international human rights law, as applicable' (or similar wording), ${ }^{44}$ thus giving the (false) impression that counter-piracy operations could fall within the ambit of wartime law. However, from the words 'as applicable' accrues that the Security Council did not declare international humanitarian law to be in fact applicable; rather, it seems that the Council aimed at stressing that the use of 'all necessary measures' to suppress illicit acts is not without limitations. ${ }^{45}$

Indeed, the simple fact that law enforcement measures are taken in a context where an armed conflict is ongoing does not automatically subject them to the law of armed conflicts. Rather, it would be necessary that the enforcers are a party to the armed conflict in question and that the measures are directed against conduct featuring a direct link with the armed conflict. This is not the case for either the enforcement measures aimed at suppressing Somali

41 Tondini (n 11) 254 and 257; in more detail: Till (n 2) 316.

42 Lord Jopling, 'Draft General Report - The Growing Threat of Piracy to Regional and Global Security' (Parliamentary Assembly NATO, 5 April 2009) para $39 \quad<$ https://www.parlament.ch/centers/documents/en/atalanta-nato-2009-04-05-e.pdf> accessed 7 March 2018.

${ }^{43}$ Eg on Somalia: UNSC Res 2182 (21 October 2014) UN Doc S/RES/2182 recently renewed by UNSC Res 2385 (14 November 2017) UN Doc S/RES/2385; and Libya: UNSC Res 2292 (14 June 2016) UN Doc S/RES/2292, recently renewed by UNSC Res 2357 (12 June 2017) UN Doc S/RES/2357.

${ }^{44}$ Re Somali piracy: UNSC Res 1851 (16 December 2008) UN Doc S/RES/1851, para 6 (counter-piracy operations in Somali internal waters); re embargo enforcement: UNSC Res 2182 (n 43) para 16, and UNSC Res 2292 ( $n$ 43) para 4. By contrast, the resolutions pertaining the migrant smuggling and human trafficking in the Mediterranean only refer to human rights law, but not to $\mathrm{IHL}$ as source limiting enforcement powers: UNSC Res 2240 (9 October 2015) UN Doc S/RES/2240 and consecutive UNSC Res 2316 (9 November 2016) UN Doc S/RES/2316, and UNSC Res 2380 (5 October 2017) UN Doc S/RES/2380.

45 On limitations, see below Part IV. 
Forthcoming in: Heike Krieger/Robin Geiß (eds.), The 'Legal Pluriverse' Surrounding Multinational Military Operations, Oxford University Press, Oxford 2020

piracy $^{46}$ or for the operations enforcing the embargos imposed on Somalia and Libya, respectively. ${ }^{47}$

\section{4 'Multinational law enforcement operations'}

Multinational law enforcement operations mandated with the suppression of criminal activity at sea are often labelled as a 'Maritime Security Operation' (MSO). This obscures that they are governed by peacetime law, as the notion of an MSO is also used to refer to operations governed by the law of armed conflicts. Thus far, no uniform definition of the term exists. The Chiefs of European Navies, for example, describe MSO in the following terms:

'2. MSO are defined as those measures performed by the appropriate civilian or military authorities and multinational agencies to counter the threat and mitigate the risks of illegal or threatening activities in the maritime domain, so that they may be acted upon in order to enforce law, protect citizens and safeguard national and international interests.

3. Developing these operations will focus on terrorism, proliferation, narcotic trafficking, illegal migration, piracy and armed robbery, but might also include smuggling, the protection of national resources, energy security, the prevention of environmental impact and safeguarding sovereignty.' 48

The Dictionary of Military Terms and Associated Terms of the U.S. Department of Defense defines MSO in a crisper way as:

'Those operations to protect maritime sovereignty and resources and to counter maritime-related terrorism, weapons proliferation, transnational crime, piracy, environmental destruction, and illegal seaborne immigration. 49

These (and other definitions) ${ }^{50}$ are vague as regards the legal paradigm governing MSO: Are these law enforcement operations (criminal domain) or do they pertain to the conduct of naval warfare (military domain)? This ambiguity notably stems from references in MSO definitions to the 'safeguarding of sovereignty' (and similar wording), which is a potential goal of such operations going beyond the countering of illegal acts committed by private persons. Kraska encapsulates the qualification problem (and its consequences) when writing that MSO 'lie between simple maritime law enforcement and the conduct of naval warfare; and the division among these categories is far from clear' and that MSO 'may contemplate a greater use of force

\footnotetext{
${ }^{46}$ For a detailed account, see Geiss and Petrig (n 20) 132-36.

${ }^{47}$ Re Somalia: Magne Frostad, 'United Nations Authorized Embargos and Maritime Interdiction: A Special Focus on Somalia' in Gemma Andreone (ed), The Future of the Law of the Sea: Bridging Gaps Between National, Individual and Common Interests (Springer 2017) 226; re Libya: McLaughlin (n 32) 490; in general, see Heintschel von Heinegg and Fink (n 32) 423.

${ }^{48}$ Developing a European Interagency Strategy for Maritime Security Operations (Paper supported by the Chiefs of European Navies, 2006) 3, paras 2, 3.

49 US Department of Defense (n 19) 147.

${ }^{50}$ Eg that of the Royal Navy cited by Till (n 2) 283.
} 
than law enforcement because the threats are deemed to go beyond mere infractions and harm national interests or affect international stability. ${ }^{51}$

The newly established Operation Sea Guardian, for example, is an operation that potentially covers the full range of activities falling within an MSO. As per the words of NATO, it "will respond to threats to maritime security that straddle the boundary between defence and law enforcement' and 'will contribute to mitigate gaps in the capacity of individual countries to enforce civilian and/or military law at sea'. ${ }^{52}$ Hence, for each intervention under the umbrella of this broadly conceived operation, it is necessary (and crucial) to determine whether it amounts to law enforcement or not.

In sum, it is submitted here that the preferable term to denote operations aimed at suppressing criminal activity at sea is 'Multinational Law Enforcement Operations'. This term better reflects the binary approach (enshrined in law) between law enforcement on the one hand and conduct of hostilities on the other, and clearly shows that these operations belong to the former category. ${ }^{53}$ Yet, it is acknowledged that in times of grey zone conflicts, e.g. in the South China Sea, choosing between the two categories may be challenging. ${ }^{54}$

\section{Authorizations to Enforce the Law at Sea: The Epitome of a 'Legal Pluriverse'}

Now that the legal paradigm governing multinational operations mandated with the suppression of criminal acts by non-state actors has been identified - peacetime law - we can drill down on the legal bases authorizing multinational forces and/or contributing states to enforce the law at sea. ${ }^{55}$ The brevity of this chapter does not allow for a full account of the rules governing enforcement jurisdiction at sea; rather, the intent is to explain how different legal sources interact and together form an intricate jurisdictional framework. After demonstrating that authorizations to enforce the law at sea are measure-specific rather than wholesale (4.1), the basic jurisdictional rules contained in UNCLOS, which are maritime zone-specific, are briefly explained (4.2). We then turn to more specific rules - contained in various legal sources, notably UNCLOS itself, treaties on transnational crime and Security Council resolutions - which derogate from the basic jurisdictional rules for specific offences (4.3). ${ }^{56}$ Finally, we conclude that jurisdiction at sea is not only measure-, maritime zone-, and offence-specific, but also mandate-

51 James Kraska, 'Military Operations' in Donald R Rothwell, Alex G Oude Elferink, Karen N Scott, Tim Stephens (eds), The Oxford Handbook on the Law of the Sea (Oxford University Press 2015) 873.

52 NATO, 'Operation Sea Guardian' (n 23).

${ }^{53}$ See Tondini (n 11) 253-54, using the term MLE to denote to policing operations by navies.

54 See Lyle Morris, 'Blunt Defenders of Sovereignty: The Rise of Coast Guards of East and Southeast Asia' [2017] 70 Naval War College Review 75.

55 This Chapter rests on the premise that states do not possess enforcement jurisdiction outside their territory, unless a permissive rule under international law confers them the authority to enforce the law: see eg Douglas Guilfoyle, Shipping Interdiction and the Law of the Sea (Cambridge University Press 2009) 7-8.

${ }^{56}$ What is more, it is necessary to implement the authorizations under international law into domestic law: McLaughlin (n 32) 468. 


\section{Forthcoming in: Heike Krieger/Robin Geiß (eds.), The 'Legal Pluriverse' Surrounding}

Multinational Military Operations, Oxford University Press, Oxford 2020

specific as the mandate of a given multinational operation may not extend to the whole range of enforcement measures that international law allows (4.4). Overall, the legal framework governing enforcement jurisdiction at sea is arguably the epitome of a 'legal pluriverse'.

\subsection{Authorizations are measure-specific: no wholesale enforcement jurisdiction}

First, it must be noted that jurisdiction to enforce the law in international waters or against foreign-flagged vessels is never wholesale; rather, states are generally only authorized to take specific types of enforcement measures. ${ }^{57}$ This warrants a closer look into the gamut of measures that could potentially be taken by multinational naval forces.

It is not uncommon for a (multinational) law enforcement operation at sea to be referred to as a 'Maritime Interdiction Operation' (MIO), which NATO defines as '[a]n operation conducted to enforce prohibition on the maritime movement of specified persons or material within a defined geographic area'. ${ }^{58}$ At times, this term is used interchangeably with 'Maritime Interception Operation'. ${ }^{59}$ Either way, there is no agreed understanding of which enforcement measures fall within the ambit of the terms 'interdiction' and 'interception', respectively. Some sources adopt a broad understanding of the concept of 'interdiction', and use it to describe a two-step process comprised of 'boarding/searching' (boarding, inspection, and search of a ship) and 'seizure' (arresting the vessel and/or persons and seizing the cargo). ${ }^{60}$ Other sources build on a narrower understanding of the terms 'interdiction' and 'interception', respectively, using them to denote 'boarding/searching' only (i.e. what Article 110 UNCLOS authorizes under the heading of 'right of visit'). ${ }^{61}$

Leaving aside the lack of consensus on the concept of 'Maritime Interdiction/Interception Operation', in substance it is an operational term rather than a legal one, ${ }^{62}$ and more generic than specific, encompassing various types of enforcement measures. Hence, for an assessment of the legal rules that govern the powers of multinational naval forces, the concept is not particularly helpful. Rather, such evaluations can only be made with respect to a specific type of measure (e.g. arrest of a suspect or seizure of cargo) that states or multinational forces may

${ }^{57}$ Even the seemingly wholesale enforcement powers authorized by UNSC Res 1846 (n 5) ('to use... all necessary means') allow no more than those authorized under Art 105 UNCLOS (n 17): see Geiss and Petrig (n 20) 9, which mentions the example where the flag state grants consent to a third state to interdict its vessel: such permission to board seldom automatically includes permission to seize and is thus only a partial waiver of flag state jurisdiction.

58 NATO, 'Maritime Interdiction Operation' (Official NATO Terminology Database, Record 9077) $<$ https://nso.nato.int/natoterm/content/nato/pages/home.html> accessed 15 January 2018.

59 Heintschel von Heinegg and Fink (n 32) 422, use the terms interchangeably after pointing out potential differences; U.S. Navy, Marine Corps and Coast Guard, 'The Commander's Handbook on the Law of Naval Operations' (Department of the Navy Office of the Chief of Naval Operations and Headquarters, US Marine Corps, Department of Homeland Security and US Coast Guard August 2017) para 4.4.4. <http://www.jag.navy.mil/distrib/instructions/CDRs_HB_on_Law_of_Naval_Operations_AUG17.pdf> accessed 7 March 2018. (hereafter 'The Commander's Handbook on the Law of Naval Operations').

${ }^{60}$ Eg Guilfoyle (n 55) 4; 'The Commander's Handbook on the Law of Naval Operations' (n 59) para 4.4.4.

${ }^{61}$ Papastavridis (n 33) 1, eg, uses interception as a synonym for the right of visit.

62 Heintschel von Heinegg and Fink (n 32) 423. 


\section{Forthcoming in: Heike Krieger/Robin Geiß (eds.), The 'Legal Pluriverse' Surrounding}

Multinational Military Operations, Oxford University Press, Oxford 2020

take in the course of an operation. Thus, a closer look at the types of measures that law enforcement operations at sea potentially entail is advised.

To begin with, intelligence measures are necessary in order to identify and detect illegal conduct at sea. With regard to ships suspected of engaging in conduct prohibited by international law, the possible measures encompass their stopping, boarding, and inspection/searching. If suspicion is confirmed, the ships and/or cargo may be seized and/or destroyed or disposed of in another way (e.g. the selling of items prohibited by embargo measures). As regards persons on board suspected of engaging in illicit activity, measures range from arrest and detention to transfer for prosecution.

All mentioned measures belong to the category of enforcement jurisdiction, which must be distinguished from adjudicative jurisdiction. ${ }^{63}$ The latter entails the authority to take measures related to the investigation and prosecution of alleged offences. Since multinational naval forces do not have adjudicative jurisdiction (rather, it remains within the ambit of states), it is not further discussed here.

\subsection{Authorizations are maritime zone-specific: UNCLOS' basic jurisdictional rules}

In order to decide whether an actor has the power to take a specific enforcement measure, the first source to consult is UNCLOS, which strikes a balance between the competing interests of different types of states and, as part of this endeavour, allocates enforcement jurisdiction to the port, coastal, flag, and/or boarding state. ${ }^{64}$ Thereby, UNCLOS pursues a maritime zonedriven approach and formulates basic jurisdictional rules for each zone - notably internal waters, territorial sea, and the high seas ${ }^{65}$ - which are to be followed unless derogated from by more specific rules, to which we turn in the next Section (4.3).

Put simply and starting closest to the shore and then moving seawards, these basic jurisdictional rules are as follows. The internal waters - comprising the waters situated landward of the baseline and ports - are considered to come within a state's territorial jurisdiction. As a consequence, ships entering these waters are, as a general rule, subject to the primary enforcement jurisdiction of the port state. ${ }^{66}$ Seawards from the baseline lies the territorial sea, a belt of water of at most 12 miles breadth, over which the coastal state exercises sovereignty. ${ }^{67}$ Hence, the coastal state is, as a general rule, allowed to take enforcement measures against

63 This article rests on the three-fold categorization of jurisdiction: to prescribe, enforce and adjudicate: see Guilfoyle ( $n$ 55) 7-9. The jurisdictional rules of UNCLOS ( $n$ 17) do not always neatly distinguish between these two forms of jurisdiction: eg Art 27 UNCLOS (n 17) using the term 'criminal jurisdiction' to refer to both enforcement ('to arrest...') and adjudicative ('to investigate...') jurisdiction.

${ }^{64}$ Guilfoyle (n 55) 4.

65 There are additional maritime zones (eg the contiguous zone and the exclusive economic zone), which are not discussed here; for a more extensive account of enforcement powers in the different maritime zones, see Natalie Klein, Maritime Security and the Law of the Sea (Oxford University Press 2011) Chapter 3.

${ }^{66}$ For a more detailed account, see Erik J Molenaar, 'Port and Coastal States' in Rothwell, Oude Elferink, Scott and Stephens (n 51) 280-303.

${ }^{67}$ UNCLOS (n 17) Art 2(3). 
vessels in these waters engaged in criminal activity. ${ }^{68}$ Finally, on the high seas, the basic rule under the law of the sea is that the flag state has exclusive enforcement jurisdiction. ${ }^{69}$

In sum, the basic jurisdictional rules under the law of the sea are maritime zone-specific; for each zone, a different type of state (the port, coastal, or flag state) has, as a general rule, primary and exclusive enforcement jurisdiction. However, regarding jurisdiction at sea, this is not the end of the story: for specific offences, these basic jurisdictional rules are derogated from due to the presence of more specific rules, to which we turn now.

\subsection{Authorizations are offence-specific: special rules derogating from UNCLOS' basic jurisdictional rules}

Since the basic jurisdictional rules of UNCLOS do not apply if a specific authorization exists in relation to a specific type of offence, enforcement jurisdiction at sea is not only maritime zonespecific, but also offence-specific. ${ }^{70}$ This makes jurisdiction at sea an intricate matter, especially when taken together with the fact that the specific rules derogating from the basic rules stem from various legal sources, three of which we turn to now: UNCLOS itself, multilateral treaties, and Security Council resolutions. ${ }^{71}$

\subsubsection{Derogations contained in UNCLOS}

The first source of offence-specific authorizations overriding the UNCLOS basic jurisdictional rules is UNCLOS itself. Given the brevity of this chapter, these rules cannot be described in full, but it suffices to provide a few examples to illustrate the mechanism.

As regards the high seas, for instance, Article 92(1) stipulates that the flag state has exclusive jurisdiction (basic rule) 'save in exceptional cases expressly provided for ... in this Convention' (derogation rule). Article 110 UNCLOS is an example of such a rule: it authorizes every state (and not just the flag state) to board a ship from which it can be reasonably expected that it engages in one of the listed offences, notably slavery and piracy. For the latter offence, Article 105 UNCLOS provides even more far-reaching powers and allows every state to seize a pirate ship and property on board and to arrest the suspects.

UNCLOS contains such specific jurisdictional rules derogating from the otherwise exclusive flag state jurisdiction only for a limited set of offences: notably for piracy, slave trade, and

68 UNCLOS (n 17) Art 25; Richard A Barnes, 'Article 25' in Alexander Proelss (ed), United Nations Convention on the Law of the Sea: A Commentary (C.H. Beck/Hart 2017) 223, para 1; and Richard A Barnes, 'Article 27' in Proelss (ibid) 234, para 9.

69 UNCLOS (n 17) Art 92(1); in detail: Robin Churchill and Vaughan Lowe, The Law of the Sea (3rd edn, Manchester University Press 1999) 208-20.

70 Klein (n 65) 62, writes that jurisdiction is different 'according to what particular threat to maritime security is being addressed'; this is arguably imprecise because a threat often encompasses various offenses (eg the threat of piracy may inter alia fulfil the offense of piracy as defined in Art 101 UNCLOS (n 17), hostage taking as defined in Art 1 Hostage Convention ( $n$ 34), and Art 3 SUA Convention ( $n$ 34) offences, armed robbery at sea, etc.); and for these offences, jurisdiction to enforce is regulated differently.

71 Since this Chapter focuses on multinational operations, bilateral treaties as a source containing derogation rules are not discussed here; on this, see eg Guilfoyle (n 55) 246-54. 
unauthorized broadcasting. ${ }^{72}$ However, there are other offences where the states competent under the basic jurisdictional rules are not willing and/or able to enforce the law; in these cases, treaties other than UNCLOS and Security Council resolutions may remedy the situation by allocating jurisdiction to third states.

\subsubsection{Derogations contained in treaties}

It is UNCLOS itself that foresees the possibility that treaties derogate from its (jurisdiction) rules. First of all, Article 311(3) UNCLOS allows inter se agreements, provided they do not disturb the object and purpose of the treaty, do not affect the basic principles of UNCLOS, and do not affect the rights and obligations of third states under UNCLOS. Doctrine suggests that an agreement between a number of states to derogate inter se from jurisdictional rules (e.g. from the flag state principle) is permissible. ${ }^{73}$ Second, basic jurisdictional rules of UNCLOS stipulate that specific treaty rules prevail. For example, Article 92(1) UNCLOS provides that flag state jurisdiction is exclusive 'save in exceptional cases expressly provided for in international treaties'. ${ }^{74}$ This fits with the framework nature of UNCLOS, which limits itself to cornerstone rules (here, the maritime zone-specific basic jurisdictional rules) that are complemented by more detailed, subject-matter related external rules (here, offence-specific jurisdictional rules). ${ }^{75}$ This mechanism allows UNCLOS 'to deal with change' ${ }^{16}$ - notably, a changing security landscape.

Indeed, a number of treaties dealing with transnational offences - such as the SUA Convention and its 2005 Protocol, ${ }^{77}$ the Protocols on Human Trafficking and Migrant Smuggling, and the UN Drug Convention ${ }^{78}$ - contain jurisdictional provisions. Yet, they chiefly pertain to prescriptive and adjudicative jurisdiction, and do not touch upon enforcement jurisdiction at all or transpire from a reluctance to encroach on the basic jurisdictional rules of the law of the sea in an all too general way. The SUA Convention illustrates this quite well: While it requires state parties to make the offences defined in the Convention 'punishable by appropriate penalties' under their domestic law (prescriptive jurisdiction) and to establish criminal jurisdiction if the offence features specific links with the state in question (adjudicative jurisdiction), ${ }^{79}$ enforcement

\footnotetext{
72 See UNCLOS (n 17) Arts 105, 109(4) and 110; UNCLOS (n 17) Art 108 (on drug trafficking) is not a jurisdictional rule, but turns on cooperation.

${ }^{73}$ Nele Matz-Lück, 'Article 311' in Proelss (n 68) 2016, para 14.

${ }^{74}$ Churchill and Lowe (n 69) 209.

${ }^{75}$ Robin R Churchill, 'The 1982 United Convention on the Law of the Sea' in Rothwell, Oude Elferink, Scott and Stephens (n 51) 30.

76 See Irina Buga, 'Between Stability and Change in the Law of the Sea Convention: Subsequent Practice, Treaty Modification, and Regime Interaction' in Rothwell, Oude Elferink, Scott and Stephens (n 51) 46.

77 Protocol of 2005 to the Suppression of Unlawful Acts Against the Safety of Maritime Navigation (adopted 14 October 2005, entered into force 28 July 2010) IMO Doc LEG/CONF.15/21 (hereafter 2005 SUA Protocol).

78 United Nations Convention against Illicit Traffic in Narcotic Drugs and Psychotropic Substances (adopted 20 December 1988, entered into force 11 November 1990) 1582 UNTS 95 (hereafter UN Drug Convention).

${ }^{79}$ SUA Convention (n 34) Arts 5 and 6.
} 
jurisdiction is explicitly excluded from the scope of the treaty. ${ }^{80}$ The boarding provision added by the 2005 SUA Protocol remedied this lacuna only partially because it is still heavily predicated on flag state consent. ${ }^{81}$ Furthermore, the clause is territorially confined to ships 'located seaward of any State's territorial sea' and thus inapplicable regarding armed robbery at sea (an offence essentially amounting to 'piracy' in the territorial waters). It was only through authorization of the Security Council - another source of derogation to which we turn now - that the respective enforcement powers to counter armed robbery in the territorial sea of Somalia were provided for.

\subsubsection{Derogations contained in Security Council resolutions}

In theory, the basic jurisdictional rules of UNCLOS together form a complete and wellbalanced system with no jurisdictional loopholes. In practice, however, this jurisdictional framework often proves to be inadequate because it is based on the assumption that states actually exercise their jurisdiction. For a variety of reasons, however, this is not always the case. For instance, failed or failing states may lack the capacity to effectively control their ports and police their territorial sea. Further, the practice of flag of convenience entails that a significant number of ships are registered in states with a poor enforcement record; 82 and the flag state may at times even have an interest in the commission of the illegal act, which may also hold true for a state subject to an embargo. This lack of enforcement by the competent state fosters the ideal climate for criminality to blossom. In exceptional cases, the Security Council has thus stepped in and authorized third states to enforce the law.

It did so regarding Somali-based piracy and authorized all states and regional organizations to '[e]nter into the territorial waters of Somalia' and to use therein 'all necessary means to repress acts of piracy and armed robbery at sea'. ${ }^{83}$ In the (nota bene Chapter VII-based) resolution, the Council used every single opportunity to stress Somalia's sovereignty and to emphasize the request by and consent of the Somali government to enforcement operations by third states in its territorial sea. ${ }^{84}$ This evidences once more the overarching reluctance to encroach upon a coastal state's jurisdiction and to weigh security concerns over sovereignty concerns. It also explains why the Security Council has thus far refrained from authorizing enforcement action against migrant smuggling vessels in Libyan waters. ${ }^{85}$ However, the Council did so for the high seas; concretely, it authorized states and regional organizations 'to inspect on the high seas off the coast of Libya vessels that they have reasonable grounds to suspect

\footnotetext{
${ }^{80}$ Art 9 leaves no doubt about it. See also Protocol on Migrant Smuggling (n 17) Arts 4, 8, 9.

${ }^{81}$ According to 2005 SUA Protocol (n 77) Art 8bis(5)(c), as a general rule, express flag state authorization is required; however, according to sub-para (d) and (e) a State (when becoming a party to the Protocol) may notify that its consent is presumed if after four hours no response is given, or grant advance consent in general.

82 Alexander J Marcopoulos, 'Flags of Terror: An Argument for Rethinking Maritime Security Policy Regarding Flags of Convenience' [2007] 32 Tulane Maritime Law Journal 277, 294-98.

83 USNC Res 1846 ( $n$ 5) para 10 (most recently renewed by UNSC Res 2383 (n 20)).

${ }^{84}$ UNSC Res 1846 (n 5) preambular paras 3, 6-7 and paras 10-11.

${ }^{85}$ Giorgia Bevilacqua, 'Exploring the Ambiguity of Operation Sophia Between Military and Search and Rescue Activities' in Andreone (n 47) 176-78.
} 
are being used for migrant smuggling or human trafficking from Libya' and to seize them. ${ }^{86}$ While the Security Council broke with a cornerstone rule of the law of the sea - exclusive flag state jurisdiction - it tried to conceal this by relying on the concept of 'good faith efforts', which it introduced in the context of embargo enforcement authorizations. ${ }^{87}$ That is, before using the authority provided by the respective resolution, enforcers must make 'good faith efforts to obtain the consent of the vessel's flag State'. ${ }^{88}$

Even if authorizations granted by the Security Council are limited in terms of their material, geographical, and temporal scope of application (they pertain to a specific offence occurring in a specific area and are generally only granted for one year, subject to renewal), reluctance to overtly break with the basic jurisdictional rules of UNCLOS transpires from these resolutions. This reluctance is underlined by the emphasis present in each of these resolutions that they shall not affect any rights or obligations under the law of the sea, including UNCLOS, and shall not be considered as establishing customary international law. ${ }^{89}$

In sum, the UNCLOS doors are theoretically wide open for specific rules derogating from its basic jurisdictional rules; yet, in practice, the shift away from these cornerstone rules is a rather hesitant undertaking. Sovereignty and the freedom of the high seas, axioms on which the basic rules of UNCLOS rest, are values that are not easily put aside.

\subsection{Authorizations are mandate-specific: may not extend to all measures authorized by international law}

At first glance, the rules conferring enforcement jurisdiction, which have been discussed above, appear to be addressed to states only - with the exception of Security Council resolutions explicitly authorizing regional organizations to take enforcement measures at sea. ${ }^{90}$ The EU, however, is a party to UNCLOS and to a good number of treaties aimed at the suppression of criminal phenomena; ${ }^{91}$ the jurisdictional rules addressed to states thus apply mutatis mutandis to the EU. ${ }^{92}$ Yet, this does not imply that EU-led naval forces can act upon all authorizations contained in these treaties without further ado. Rather, the EU's Common Foreign and Security Policy, under the roof of which EUNAVFOR's Operation Atalanta and

86 UNSC Res 2240 (n 44) paras 7-8.

${ }^{87}$ See, eg, UNSC Res 2182 ( $n$ 43) para 16; UNSC Res 2292 (n 43) para 3.

88 UNSC Res 2240 ( $n$ 44) para 7; Brian Wilson, 'The Mediterranean Migrant Crisis: Key Considerations for the UN Security Council' [2015] Harvard National Security Journal 1, 5, criticizes that this injects an unwarranted degree of uncertainty for the operations, including 'whether there is an expected time to allow for a flag response, whether a request needs to be in writing, and who is authorized to make and receive such requests'.

89 UNSC Res 2240 (n 44) para 11; UNSC Res 1846 (n 5) para 11.

90 UNCLOS (n 17) Art 92(1), eg, stipulates that 'every State' may seize a pirate ship; by contrast, UNSC Res 1846 (n 5) para 1, explicitly authorizes 'States and regional organizations' to counter piracy and armed robbery at sea in Somali territorial waters.

${ }^{91} \mathrm{Eg}$ the Protocol on Migrant Smuggling (n 17), the Protocol on Human Trafficking (n 34), and the UN Drug Convention (n 78); however, the EU is not a party to the SUA Convention (n 34) or the 2005 SUA Protocol ( $\mathrm{n} 77$ ), which were both adopted under the auspices of the International Maritime Organization.

${ }_{92}$ For UNCLOS (n 17), this is spelled out explicitly in UNCLOS (n 17) Art 1(2)(2) juncto Art 305(1)(f). 
Operation Sophia reside, remains intergovernmental rather than supranational in nature, and the establishment of an operation requires a Council Decision. ${ }^{93}$ This decision defines the mandate, which does not necessarily extend to the use of all measures allowed under international law. ${ }^{94}$

By contrast, NATO is not a party to the treaties conferring power to enforce the law at sea. Yet, states are free to either exercise their enforcement powers together with other states (eg in naval coalitions such as the Combined Maritime Forces), or even to confer their enforcement powers to international organizations, such as NATO. ${ }^{95}$ However, each operation and the scope of the mandate has to be decided by the North Atlantic Council, in which all member states are represented. ${ }^{96}$ At times, the mandate does not cover all phases of an operation and thus only extends to some of the measures that international law allows states to take. For example, NATO's counter-piracy operations in the Gulf of Aden were limited to disrupting and deterring pirate attacks and did not extend to the arrest, detention, and transfer of piracy suspects - as the EU-led operations do. ${ }^{97}$

\section{Attaching Strictures: Moving Outside the 'Legal Universe'}

Thus far, the focus has been on a complex legal framework conferring multinational forces and/or contributing states the power to enforce the law at sea. Now, we change perspective and ask what strictures attach to enforcement measures taken by multinational forces and/or contributing states, and where they stem from. Hence, this Part turns on rules protecting persons subject to enforcement measures (i.e. suspects arrested, detained, and/or transferred for prosecution) whereby the emphasis is on procedural safeguards. ${ }^{98}$

Intuitively, one would think that the rules authorizing enforcement measures at sea (which imply coercion and, ultimo, the use of force) include limitations on their exercise. Yet, this is hardly the case. The primary reference point in terms of jurisdiction at sea is UNCLOS - a body of law known for its 'difficulty to configure persons as the beneficiaries of rights and the recipient

\footnotetext{
${ }^{93}$ See Graham Butler and Martin Ratovich, 'Operation Sophia in Uncharted Waters: European and International Law Challenges for the EU Naval Mission in the Mediterranean Sea' [2016] 85 Nordic Journal of International Law 235, 238-39.

${ }^{94}$ See, eg, Council Decision (n 24) Art 2, which foresees different phases during which different types of enforcement measures can be taken by EUNAVFOR.

${ }^{95}$ Principle of attributed power: Henry G Schermers and Niels M Blokker, International Institutional Law: Unity within Diversity (5th edn, Martinus Nijhoff 2011) 157-59, paras 209-209A.

${ }_{96}^{96}$ North Atlantic Treaty (adopted 4 April 1949, entered into force 24 August 1949) 34 UNTS 243, Art 9; Peter M Olson, 'A NATO perspective on applicability and application of IHL to multinational forces' [2013] 95 International Review of the Red Cross 653, 654.

97 Anna Petrig, Human Rights and Law Enforcement at Sea: Arrest, Detention and Transfer of Piracy Suspects (Brill Nijhoff 2014) 54-55; see also below Part IVIA.

${ }^{98}$ Of interest (but not discussed here) are the rules limiting the use of force or regulating the substantive treatment of suspects on board warships.
} 
of duties', which does not confer any human rights to persons. ${ }^{99}$ Treaties aimed at the suppression of transnational crimes - which also contain authorizations to enforce the law at sea - are not a rich source as regards procedural safeguards for suspects, either. For example, the SUA and Hostage Conventions entail a single procedural safeguard: the right to consular assistance (akin to Article 36 of the Vienna Convention on Consular Relations), a guarantee that was drafted with a view to apply to persons detained on land, and thus its applicability at sea is open to question. ${ }^{100}$ Even the 2005 SUA Protocol - which stands out because it is arguably the sole treaty authorizing enforcement measures at sea containing a detailed list of safeguards limiting these powers - is not very helpful in terms of procedural safeguards. It requires the 'enjoyment [by the suspects] of all rights and guarantees in conformity with the law of the State in the territory of which that person is present and applicable provisions of international law, including international human rights law'. ${ }^{101}$ Hence, the provision simply refers to the applicable law; it does not, however, identify specific legal bases, let alone set its own standard. Such a referential approach is also followed by the Security Council when authorizing 'all necessary means' to suppress illegal acts at sea; while earlier resolutions generally remained moot in terms of strictures attached to the exercise of authorized enforcement measures, newer resolutions request that they be taken in compliance with applicable international law or human rights law more specifically. ${ }^{102}$

Since the legal bases authorizing enforcement powers are either conspicuously silent as regards the strictures imposed on their exercise or follow a purely referential approach, we must turn to the (referenced) external legal sources: first, we look at domestic law - a legal source that plays a pivotal role even in operations of a multinational character (5.1) - and, second, at international human rights law (5.2). However, there are acts and decisions taken in the course of a multinational law enforcement operation at sea which are not governed by law at all; for example, the decision to transfer a piracy suspect, which is a result of negotiations rather than a legal procedure (5.3).

\subsection{Domestic law: pivotal even in multinational operations}

Domestic law, which encompasses norms protecting persons seized at sea, plays a pivotal role - even in law enforcement operations that are multinational in nature. For this, there are at least three reasons.

\footnotetext{
${ }^{99}$ Rather, UNCLOS (n 17) addresses persons either as objects of protection (eg Art 98) or repression (eg Art 105): Irini Papanicolopulu, 'The Law of the Sea Convention: No Place for Persons?' [2012] 27 International Journal of Marine and Coastal Law 867, 867 and 873.

100 In detail: Petrig (n 97) 310-12.

${ }^{101}$ Art 10(2) introduced to the SUA Convention (n 34) by the 2005 SUA Protocol ( $n$ 77). By contrast, the Protocol establishes its own standard for the use of force and human treatment of persons on board: see Art 8bis(9) and 8bis(10)(1)(a)(ii) and Art 10(2) introduced to the SUA Convention (n 34) by the 2005 SUA Protocol (n 77).

102 See, eg, UNSC Res 2240 (n 44) para 10; UNSC Res 2182 (n 43) 16; and UNSC Res 2292 (n 43) para 4; in detail: Anna Petrig, 'The Role Accorded to Human Rights in Security Council Maritime Resolutions' in Kiara Neri (ed), Le Conseil de sécurité des Nations Unies et la mer/ The United Nations Security Council and the Sea (Editoriale Scientifica 2018, forthcoming) Part III.
} 
First of all, as we have seen, the mandate of a specific multinational mission does not necessarily cover all phases of the operation. For example, NATO's counter-piracy operations in the Gulf of Aden followed a deter-and-disrupt strategy and operated a catch-and-release scheme. NATO, unlike the EU, did not conclude any transfer agreements for the purpose of prosecuting seized suspects in states of the region. If a contributing state nevertheless decided to arrest and detain a suspect with a view to his prosecution, it did so in its national capacity; thus, domestic law governed the deprivation of liberty, including the procedural safeguards to be granted to arrested or detained suspects. ${ }^{103}$

Second, even if the mandate of a multinational law enforcement operation at sea covers arrest, detention, and transfer for prosecution - such as EUNAVFOR's Operation Atalanta ${ }^{104}$ some contributing states (e.g. France and Spain) prefer to revert back to national control if specific situations arise, notably if a ship flying their flag comes under attack. As soon as a contributing state reverts back to national control - which requires nothing more than sending a message to the EUNAVFOR Operational Headquarters - enforcement measures are taken under national authority and domestic law therefore applies. ${ }^{105}$

Third, in multinational operations at sea, contributing states retain a certain degree of command and control. For example, the arrest, detention, and transfer of piracy suspects is neither a process controlled entirely by EUNAVFOR nor do these matters fall solely within the competence of the respective contributing state. ${ }^{106}$ Hence, domestic law remains important, yet opinions differ as to what moment domestic law comes to bear. Essentially, there are two approaches that states contributing to counter-piracy operations in the Gulf of Aden follow. According to the first approach, termed here the 'ordinary suspect approach', domestic law applies from the very moment a suspect is arrested by naval personnel of the respective state. Spain, for example, applies its ordinary criminal procedural rules as soon as its troops arrest a suspect, while France enacted a specific law governing policing measures at sea, which foresees various procedural safeguards. ${ }^{107}$

103 Petrig (n 97) 54-55.

104 Council Joint Action 2008/851/CFSP of 10 November 2008 on a European Union military operation to contribute to the deterrence, prevention and repression of acts of piracy and armed robbery off the Somali coast [2008] OJ L301/33, Art 2 (as amended by Council Decision 2010/766/CFSP of 7 December 2010 amending Joint Action 2008/851/CFSP on a European Union military operation to contribute to the deterrence, prevention and repression of acts of piracy and armed robbery off the Somali coast [2010] OJ L327/49, Art 1).

105 Petrig (n 97) 84.

106 This makes attribution of conduct violating international law an intricate issue; see Re 'MV Courier' [2014] 4 A 2948/11 (Oberverwaltungsgericht Nordrhein-Westfalen) where the core question was whether the decision to transfer a piracy suspect to Kenya is attributable to Germany or rather to EUNAVFOR Operation Atalanta.

107 Loi française $n^{\circ}$ 2011-13 du 5 janvier 2011 relative à la lutte contre la piraterie et à l'exercise des pouvoirs de police en l'Etat de mer (2011); see (Loi française $n^{\circ}$ 2011-13); see Luc Briand, 'Lutte contre la piraterie maritime: la France renforce son arsenal législatif. À propos de la loi $n^{\circ} 2011-13$ du 5 janvier 2011 relative à la lutte contre la piraterie et à l'exercice des pouvoirs de police en l'État en mer' [2011] Gazette du Palais 8-12. 

Multinational Military Operations, Oxford University Press, Oxford 2020

States following the second approach, referred to here as the 'extraordinary suspect approach', take the stance that suspects deprived of their liberty are not 'ordinary' criminal suspects (such as those arrested by these states within their territory) to which domestic law and the respective procedural safeguards apply. Norway, for example, uses the term 'EU detainees', while Italy's Corte di Cassazione refers to arrest occurring at sea as 'sui generis apprehension'; 108 and Germany has argued that its troops do not act within a criminal prosecution framework (nicht strafverfolgend tätig) when seizing piracy suspects, and their detention thus qualifies as 'international law custody' (völkerrechtlicher Gewahrsam). ${ }^{109}$ These states only apply domestic law to suspects in the (rare!) case that they decide to prosecute a piracy suspect in their domestic courts. Before such a decision is taken, however, suspects are in 'legal limbo': the EU cannot guarantee procedural safeguards (e.g. the right to be brought promptly before a judge) and the seizing state is not willing to do so. If suspects are ultimately released, their deprivation of liberty was never subject to judicial control; and, in cases of transfer, these states argue that it suffices if the suspects are brought before a judge in the receiving state - a problematic view, as we will see in the next Section (5.2). ${ }^{110}$

In sum, domestic law (partially or entirely) governs enforcement measures taken at sea by states contributing to multinational operations. Yet, in each of the aforementioned situations, a common problem remains: domestic legal acts regulating law enforcement (and providing for procedural safeguards) may not apply to a state's navy because the personal scope of application only covers traditional law enforcement agencies - i.e. the police. For example, this holds true for both the Danish Administration of Justice Act and the German Code of Criminal Procedure. ${ }^{111}$ At the same time, specific rules governing law enforcement measures carried out by naval forces may not exist (yet). Or they are contained in classified, or at least non-public, military documents (such as Standard Operating Procedures or Rules of Engagement) not living up to the quality of law standard developed by the European Court of Human Rights, which requires that the legal basis providing for deprivation of liberty and governing the relevant procedure must be 'sufficiently accessible, precise and foreseeable in its application, in order to avoid all risk of arbitrariness'. ${ }^{112}$ Hence, there is a clear lack of coordination between the option under the international law of the sea to use warships and military personnel for law enforcement at sea (and an operational reality where navies indeed increasingly police the sea) and domestic law. This results in normative uncertainty, if not normative gaps, vis-à-vis the strictures attaching to the exercise of enforcement powers.

\footnotetext{
108 Stefano Dominelli, 'Transfer of Suspected Pirates and Human Rights: Axiomatic Theories, State Practice, and Judicial Interventions - A European Perspective on Some Possible Shortcomings of the Current International Legal Framework' [2017] 3 Diritto Marittimo 647, 666.

${ }^{109}$ Claus Kre $\beta$, 'Die moderne Piraterie, das Strafrecht und die Menschenrechte: Gedanken aus Anlass der deutschen Mitwirkung an der Seeoperation ATALANTA' in Dieter Weingartner (ed), Die Bundeswehr als Armee im Einsatz: Entwicklungen im nationalen und internationalen Recht (Nomos 2010) 104.

110 On the two approaches, see Petrig (n 97)118-26.

111 Ibid 58-59 (Denmark) and 123-24 (Germany).

112 ECtHR, Ismoilov and others v Russia, App no 2947/06, Judgment, 24 April 2008, para 137; Petrig (n 97) 231 and 240.
} 


\section{Forthcoming in: Heike Krieger/Robin Geiß (eds.), The 'Legal Pluriverse' Surrounding} Multinational Military Operations, Oxford University Press, Oxford 2020

\subsection{International law: human rights law not yet refined for the maritime context}

As regards strictures imposed on actors enforcing the law, international human rights law is an obvious body of law to turn to. However, the procedural safeguards contained in human rights treaties were mainly drafted (and interpreted) with a view to applying to domestic and land-based law enforcement activities carried out by organs of that respective state. None of these assumptions are fulfilled in the context of multinational military operations tasked with the suppression of criminality at sea: not only do they take place extraterritorially, but in the maritime environment as well, and - most importantly - in close cooperation with different states and/or regional organizations.

Today, it seems difficult for states to maintain that human rights do not apply at all in the maritime context; ${ }^{-13}$ however, the requirements for triggering their application in an extraterritorial maritime environment are not yet entirely clear. ${ }^{114}$ Further, a series of questions arises from the cooperative approach taken to law enforcement at sea, namely which state bears the responsibility to grant specific rights. The following example on the right to be brought promptly before a judge in a case of arrest or detention ${ }^{115}$ illustrates this.

While much has been written on the notion of 'promptness', ${ }^{116}$ another key issue has received considerably less attention: whether suspects seized at sea must be brought before the judge of the seizing state or whether it suffices that judicial control takes place in a third state (generally the state to which the suspect is transferred for prosecution). In the Courier Case, where the legality of an arrest carried out by the German Navy while contributing to EUNAVFOR's Operation Atalanta was at issue, the German Administrative Court of Cologne supported the view of the Federal Government of Germany: the right to liberty was respected, even though the suspect was not brought before a German judge, because he was brought before a Kenyan judge (seven days after his arrest). ${ }^{117}$ The Court supported its findings with reference to the Rigopoulos and Medvedyev cases decided by the European Court of Human

\footnotetext{
${ }^{113}$ France argued this way in ECtHR, Medvedyev and Others v France App no 3394/03, Grand Chamber Judgment, 29 March 2010, para 49; today, however, it has a specific law governing enforcement measures at sea, including procedural safeguards, see (n 107).

114 Geiss and Petrig (n 20) 103-14; Kiara Neri, 'The applicability of the European Convention on Human Rights to State enforcement and control at sea' in Gemma Andreone (ed), Jurisdiction and Control at Sea: Some Environmental and Security Issues (Giannini Editore 2014) 153-68.

115 European Convention on Human Rights Convention for the Protection of Human Rights and Fundamental Freedoms (adopted 4 November 1950, entered into force 3 September 1953) ETS 5, Art 5(3) (hereafter ECHR); Art 9(3) International Covenant on Civil and Political Rights (adopted 16 December 1966, entered into force 23 March 1976) 999 UNTS 171 (hereafter ICCPR).

116 In ECtHR, Rigopoulos v Spain, App no 37388/97, Fourth Section Judgment, 12 January 1999; and Medvedyev and Others $v$ France (n 113) paras 131-34, the Court bestowed the notion of 'promptness' with a broad meaning; see also ECtHR, Ali Samatar and Others v France, App no 17110/10 and 17301/10, Judgment, 4 December 2014, paras 45-59; ECtHR, Hassan and Others v France, App no 46695/10 and 54588/10, Judgment, 4 December 2014, paras 89-104.

${ }^{117}$ Re 'MV Courier' [2011] 25 K 4280/09 (Verwaltungsgericht Köln, 25. Kammer) paras 20-26 (Germany's argument) and para 39-49 (Court's view); this aspect was not appealed.
} 
Rights. Yet, these and newer cases pertaining to the right to liberty in the maritime context ${ }^{118}$ differ on a crucial point from the scenario at hand: the suspects were not transferred to a third state, but rather brought (with some delay) before the courts of the seizing state. Hence, they do not answer the question whether a judge of the seizing state must intervene or whether a 'judge is a judge' - regardless of the state to which she or he belongs. The latter proposition cannot be maintained for a number of reasons. First, the preventive purpose of Article 5(3) ECHR - to prevent arbitrary detention, abuse of power, and ill-treatment by the very intervention of a judge - cannot be achieved if judicial control (by the receiving state) takes place after deprivation of liberty (by the seizing state) ended. Second, from the principle of equal sovereignty of states, it follows that State A (e.g. Germany) cannot ensure that a suspect transferred to Kenya is indeed brought before a judge in State B (e.g. Kenya). What is more, a Kenyan judge cannot review the legality of an arrest carried out by German forces without violating the principle of par in parem non habet iudicium. Rather, arrest and detention at sea (by the seizing state) and deprivation of liberty on land (by the receiving state) are two separate spheres, each of which falls within the purview of a different jurisdiction. Third, and finally, the very idea behind the right to see a judge is to subject the power of arrest and detention to judicial control - i.e. that authorizations to enforce the law must always be glued together with respective limitations preventing boundless state action. ${ }^{119}$

This is just one of several situations where actors involved in multinational counter-piracy operations advocated for modification of an otherwise well-established procedural safeguard. ${ }^{120}$ This underlines the need for further refinement of international human rights law for application to maritime law enforcement operations. What is arguably even more concerning than the modification of specific rights is the fact that some measures taken in the course of multinational operations are not governed by law at all - as is the case for the transfer of piracy suspects to third states for prosecution, to which we turn now.

\subsection{No law at all: enforcement measures outside the 'legal universe'}

For the offence of piracy, international law grants both universal enforcement and adjudicative jurisdiction. Despite these comprehensive authorizations, in the counter-piracy operations off the coast of Somalia, it has proven difficult to implement the basic tenet of every law enforcement operation - to bring apprehended suspects to justice - because patrolling states have been reluctant to prosecute seized suspects in their domestic courts. In light of this, EUNAVFOR concluded several transfer agreements with regional states, whereby the latter

118 Ali Samatar and Others v France (n 116); Hassan and Others v France (n 116).

119 In more detail: Anna Petrig, 'Arrest, Detention and Transfer of Piracy Suspects: A Critical Appraisal of the German Courier Case Decision' in Gemma Andreone, Giorgia Bevilacqua, Giuseppe Cataldi, Claudia Cinelli (eds), Insecurity at Sea: Piracy and Other Risks to Navigation (Giannini Editore 2013) 161-67.

${ }^{120}$ Actors involved in counter-piracy operations in the Gulf of Aden further suggested that no individual non-refoulement assessment is necessary in light of the transfer agreements concluded with states of the region, which request that suspects are granted certain human rights: see Petrig (n 97) 359-68. 


\section{Forthcoming in: Heike Krieger/Robin Geiß (eds.), The 'Legal Pluriverse' Surrounding}

Multinational Military Operations, Oxford University Press, Oxford 2020

declared their general willingness to accept piracy suspects for prosecution - subject, however, to their consent in each individual case. ${ }^{121}$

The most obvious legal mechanism to bring an alleged offender from the jurisdiction of the arresting state to the jurisdiction of the prosecuting state is extradition. Despite being the traditional and common modus operandi to acquire jurisdiction over a criminal suspect in a transnational setting, extradition has thus far never been used to bring a piracy suspect from a patrolling state's warship within the jurisdiction of the prosecuting state; ${ }^{122}$ rather, states have opted for so-called 'transfers'. The practice of Denmark contributing to NATO's counter-piracy operations and EUNAVFOR's Operation Atalanta demonstrates that the decision to transfer is issued through a process that fundamentally differs from extradition. A transfer is the result of negotiation and cooperation between two states or between a state and EUNAVFOR, rather than a surrender taking place in execution of a decision issued by an administrative and/or judicial body in a formalized procedure described in a legal act. Further, unlike in extradition proceedings, no judicial review of a decision to transfer is possible and suspects cannot exercise any procedural rights (eg formulate a non-refoulement claim). ${ }^{123}$

This example suggests that not only is the law at times unclear when applied to extraterritorial, multinational law enforcement operations at sea, but some acts and decisions are neither within the realm of legal procedures nor are they governed by law.

\section{Conclusion}

The security landscape has changed considerably in recent years. With criminal activity by non-state actors becoming one of the main maritime security threats, navies are increasingly engaged in policing operations rather than assuming naval warfare-related tasks. Such operations are not 'warfare lite', ${ }^{124}$ but rather determined by peacetime law. While this determination is rather straightforward, identifying the respective authorization to enforce the law is more complex: the basic rules of the law of the sea, which are maritime zone-specific, are derogated from by more specific rules for specific offences. These derogation rules flow from various legal sources - namely UNCLOS itself, other treaties, and Security Council resolutions (the latter likewise making jurisdiction at sea a volatile system). What is more, the mandate of a specific multinational operation may not allow for the exercise of all enforcement powers permitted under international law. Jurisdiction at sea is thus maritime zone-, offence-, and mandate-specific. Overall, the legal framework governing enforcement jurisdiction at sea is arguably the epitome of a 'legal pluriverse', yet the powers are more clearly defined than the strictures attaching to their exercise. The sources from which limitations stem are diverse as well, although a number of ambiguities and normative gaps can be identified. They are notably

121 Tim René Salomon, Die internationale Strafverfolgungsstrategie gegenüber somalischen Piraten (Springer 2017) 9-16.

122 Petrig (n 97) 41-42; there has been one single instance of extradition, but it was a unique case because the suspects were already on the European mainland.

123 Ibid 127.

${ }^{124}$ See title of Luke (n 9). 
due to the multinational character of enforcement operations, the fact that they take place in an extraterritorial maritime environment, and the navies occupying the role of lead actor rather than the police. Moreover, as the example of decisions to transfer piracy suspects illustrated, some phases of multinational law enforcement operations simply take place outside the 'legal universe' altogether.

As has been accurately pointed out, '[c]hoosing the right regime of authority for action and fully understanding the implications of that choice can make the difference between strategic success and failure' of maritime enforcement operations. ${ }^{125}$ Yet, this alone is not enough: choosing the right source of authority and observing the relevant strictures when acting upon such authorizations ultimately determines the legality and the legitimacy of multinational law enforcement operations at sea.

125 Ibid 11. 